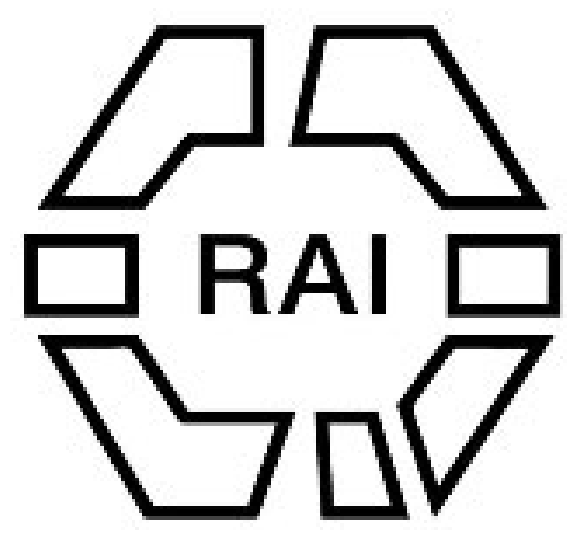

Note on Some Egyptian Antiquities.

Author(s): Villiers Stuart

Source: The Journal of the Anthropological Institute of Great Britain and Ireland, Vol. 12 (1883), pp. 324-326

Published by: Royal Anthropological Institute of Great Britain and Ireland

Stable URL: http://www.jstor.org/stable/2841947

Accessed: 16/06/2014 03:02

Your use of the JSTOR archive indicates your acceptance of the Terms \& Conditions of Use, available at http://www.jstor.org/page/info/about/policies/terms.jsp

JSTOR is a not-for-profit service that helps scholars, researchers, and students discover, use, and build upon a wide range of content in a trusted digital archive. We use information technology and tools to increase productivity and facilitate new forms of scholarship. For more information about JSTOR, please contact support@jstor.org.

Royal Anthropological Institute of Great Britain and Ireland is collaborating with JSTOR to digitize, preserve and extend access to The Journal of the Anthropological Institute of Great Britain and Ireland. 
in the two cases, and suggesting that in both localities they were to be regarded as relics of Phœnician art.

Mr. VllLiers Stuart, M.P., exhibited a copy of a funeral canopy of an Egyptian Queen, and casts of the heads of two Egyptian Kings; and read the following note:-

\section{Note on some Egyptian ANTiquities.}

By Villiers Stuart, Esq., M.P.

THE coloured plate which I now exhibit ${ }^{1}$ is the only drawing that has yet been made of one of the most remarkable relics of ancient Egyptian art that has recently been discovered. It was found in a subterranean corridor amongst a very miscellaneous collection of antiquities. There were no fewer than forty royal mummies: about half of these belong to the twentieth dynasty; but besides them were the remains of some of the most distinguished monarchs of Egyptian history. And it appeared from the inscriptions on their coffins that King Pinotem, of the twentieth dynasty, finding that wholesale robberies were going on amongst the tombs of the kings, and that he was unable to protect them while they were scattered in so many different places, had them gathered together into his own family mausoleum for safety, and there they have remained since somewhere about the time of the Trojan War until last autumn, when they were discovered by the curator of the Cairo Museum, and the whole collection were transferred thither. There were about 6,000 articles in all, including statuettes, ivory boxes, steles, and many other objects.

The original of this drawing was found lying beside the coffin of the queen in whose honour it had been made. It was in fact her funeral canopy, intended to cover the shrine of the boat in which she was conveyed across the Nile to her last resting place. It is constructed entirely of leather. When spread out it is about 22 feet long by 17 or 18 feet wide, and it covers about 200 feet superficial. It would occupy too much time to enter into the details of the design, which, however, will be found in the book I have recently published, but I may observe that the gazelle which figures so prominently on one side of it commemorates the existence of a pet of the queen's, which was found (embalmed), along with her coffin, in a wooden case made in the shape of the animal when alive. I can guarantee the colouring of this plate to be correct, and I have brought down

\section{Queen."}

1 This forms the frontispiece of my work, "The Funeral Tent of an Egyptian 
some fragments of the canopy itself for comparison : these were given me by the museum authoricies. The whole fabric is in fact a mosaic of leather work consisting of thousands of pieces of gazelle-hide of different colours, stitched together at the edges.

It will add to the interest of this subject if I mention that the queen in whose honour it was made was the contemporary of King Solomon. We know from monuments that she was the mother-in-law of King Sheshak, who took Jerusalem immediately after the death of Solomon.

I will now turn to another subject which, perhaps, is more immediately relevant to the objects of this Institute, viz., the casts of the heads of two kings of the eighteenth dynasty, which I took myself from the bas-reliefs of the tomb which I discovered and excavated at Thebes, not far from the place where the discoveries were made to which I have already alluded. It has always been accepted by Egyptologists, but without sufficient reason, that Amunoph IV and Khoun Aten were identical. It happens, however, that the owner of the tomb I have spoken of was the governor of Thebes in the time of Amunoph IV, and also during the early years of the reign of Khoun Aten, and he accordingly decorated his tomb with portraits of both the kings under whom he had served. It would be difficult to imagine a greater contrast between any two men than is here shown between the faces and figures of the two kings in question. Amunoph IV was, as you may judge from the head and shoulders I here exhibit, a stout burly personage. All the Amunophs were stout, and had also similar features and figures. Khoun Aten, on the contrary, is lean and emaciated to a degree, which almost suggests a caricature. But the difference of personal appearance is by no means the only ground on which I base my conclusions that they were distinct personages : their dress and all other surroundings, as revealed to us in this tomb, also differ entirely. The courtiers, considering that imitation is the sincerest flattery, have adopted a dress calculated to give them the same portly appearance as their master, and they are all Egyptians. Those of Khoun Aten wore a totally different dress, and were decorated with earrings, an ornament never worn by Egyptian men. Their features also are foreign, and, so far as we can judge, Semitic, as was the form of worship introduced by this king. It is to be observed that the governor of Thebes, who is represented on one side of the tomb as presenting an address to Amunoph IV, does not appear among the courtiers of Khoun Aten on the other. We see, moreover, that Amunoph IV is surrounded with all the orthodox deities of Egyptian mythology: the goddess $\mathrm{Ma}$ is protecting him; over his head is a prayer to Horus $\mathrm{Ra}$, and Amen $\mathrm{Ra}$ is also mentioned in the 
inscription. On the other side the only object of worship is the sun disc : all other Egyptian deities are excluded. It is to be observed, also, that the priests who chiselled out the face and figure of Khoun Aten after his death, in token of their detestation of his heresy, left untouched the legitimate King Amunoph IV. That fact alone would lead us to conclude that they were different personages; else why were they treated so differently. The only ground on which they were supposed to be identical was that at one time of his life Khoun Aten adopted and used the ovals of Amunoph IV; but that is not difficult to account for. Being a foreigner, and having no ovals of his own, he adopted those of his predecessor, as a matter of policy. Subsequently, however, he discontinued the use of them, and even here he is represented as using an oval in addition to those he had borrowed. The history of his occupation of the throne of Fgypt appears to be as follows:-Amunoph III, besides his Egyptian Queen Ta-i-ti, married a Semitic princess of the name of Thy: several large scarabæi are extant-one in the British Museum-recording this marriage.

We may fairly conclude that Amunoph IV was the son of Amunoph III, by his Egyptian queen, but that he had besides a daughter by Thy : this latter fact is quite certain, because in an inscription at Tel el Amama a visit of Thy is commemorated. In this inscription Thy is described as the mother of the Queen of Khoun Aten, thus making it certain that Khoun Aten was not the son of Amunoph III, even were there no other reasons for coming to that conclusion. I may mention that Maspero is my authority for the statement I have made about the inscription at Tel el Amama, but I myself found an inscription there in which the royal daughters are pointedly mentioned as daughters of the queen, Thy attributing the royal succession to her. These daughters married Egyptian subjects, who reigned in succession in their right, and finally the sister of the queen also married an Egyptian subject. He reigned in her right, thus proving conclusively that the succession was in the queen and not in the king. The tomb of Ta-i-ti, the most prominent of the tombs of the queens, stands behind the great colossal statues of Amunoph III. I have figured this queen in my "Nile Gleanings," from a painting of her which exists in this tomb in a very perfect condition; and lest there should be any doubt that she was a queen of the eighteenth dynasty, and of Amunoph, I may mention that she wears a crown which is quite peculiar to the eighteenth dynasty, and that her costume is an exact fac simile of the costumes of the queen of Amunoph I, and is also peculiar to the eighteenth dynasty. I say this because I have had it suggested that Ta-i-ti may have been a queen of the twentieth or twenty-first dynasty, a theory which is quite untenable. 